\title{
Komunikacja niewerbalna Koreańczyków na tle tradycji kulturowej. Perspektywa glottodydaktyczna
}

W obliczu wzrastającej w ostatnich latach pozycji Polski na świecie, związanej przede wszystkim ze wstapieniem do Unii Europejskiej, promocja polszczyzny wydaje się działaniem jeszcze bardziej uzasadnionym niż dotychczas. $\mathrm{Na}$ niwie uniwersyteckiej obok rozbudowujących się i nowo powstających polonistyk oraz slawistyk europejskich w kilku ostatnich dekadach studia polonistyczne rozwijają się również na Dalekim Wschodzie. Placówki naukowe $\mathrm{z}$ tego regionu, oferujące edukację $\mathrm{w}$ zakresie filologii polskiej, znajdują się w Tokio (Tokio University of Foreign Studies ${ }^{1}$ ), Pekinie (Beijing Foreign Studies University), New Delhi (University of Delhi) oraz Seulu. Z tego ostatniego ośrodka w każdym semestrze około 10 studentów polonistyki przyjeżdża na staż na Uniwersytet im. Adama Mickiewicza w Poznaniu, z którym Hankuk (Koreański) University of Foreign Studies podpisał umowę o współpracy międzynarodowej².

Idea promocji polszczyzny na Dalekim Wschodzie wiąże się z problemami wynikającymi z ogromnego kontrastu kulturowego. Proces przyswajania nowego języka i kompetencji socjolingwistycznej powinien zawsze łączyć się z poznawaniem obyczajowości obcej kultury. Funkcjonowanie w sferze społecznej (aktywność codzienna) wyraża się w działaniu praxis i w mowie lexis. Człowiek wychodzący poza swój etnos - uczący się języków obcych, czasem z bardzo odległych zakątków globu - jawić się może jako „obywatel świata", z istoty swego człowieczeństwa otwarty na inne kultury. A jako że homo sapiens to istota społeczna, która dąży do możliwie precyzyjnego i kon-

${ }^{1}$ Podaję angielskie nazwy uczelni, ponieważ oprócz nazw oryginalnych takimi właśnie posługują się uniwersytety azjatyckie.

${ }^{2}$ Właśnie dzięki koreańskim studentom przebywającym w Poznaniu powstał mój artykuł. 
trolowanego wyrażenia siebie w przestrzeni międzyludzkiej, staje obywatel świata przed zadaniem przełożenia swego kodu, zarówno lexis, jak i praxis, na kod Innego. Przybysz z Dalekiego Wschodu dążący do uzyskania pełnej kompetencji komunikacyjnej w Polsce będzie zatem adaptować się do polskiego kodu. Nie tylko językowego.

\section{Kod językowy a parajęzykowy - problemy metodyczne}

Istotnym problemem, przed którym staje każdy lektor języka obcego, jest kwestia: jakiej odmiany języka uczyć i na jakie jego elementy zwrócić szczególną uwagę. Koncentruję się na pomijanym często w glottodydaktyce aspekcie: komunikacji niewerbalnej, szczególnie ważnej w przypadku nauczania studentów pochodzących z odległego kręgu kulturowego. Skorelowanie nauczania językowego i szeroko pojętej kompetencji socjokulturowej ${ }^{3}$ jest, jak sądzę, jednym z najważniejszych wyzwań, stojących przed edukacją glottodydaktyczną.

W procesie nauczania języka obcego standardowe myślenie o celach komunikacyjnych ogranicza się zazwyczaj do komunikacji werbalnej. Uzasadnienie takiego stanu rzeczy może z jednej strony wydawać się dość jasne. Przedmiotem nauczania jest wszakże język. $Z$ drugiej jednak strony wypada postawić fundamentalne pytanie: czym jest ów język, którego uczymy? Z perspektywy glottodydaktycznej pojmujemy go przede wszystkim w kategoriach pragmatycznych: dla studenta obcokrajowca stanowi głównie narzędzie komunikacji w naturalnym środowisku, interaktywny instrument służący określonym celom praktycznym. Student obcokrajowiec będzie zatem sięgać po język nie jako strukturę sensu stricto (w takiej perspektywie pojmować go będzie w procesie uzyskiwania kompetencji lingwistycznej na wybranych zajęciach językowych z pomocą lektora), lecz jako narzędzie umożliwiające skuteczną komunikację, dla której najważniejszymi dyrektywami pozostają: ekonomia, precyzja i jednoznaczność (w zakresie zamierzonym przez nadawcę komunikatu).

Wśród postulowanych kompetencji językowych najbardziej pierwotna i najbardziej niezbędna jest umiejętność żywej i spontanicznej interakcji z rodzimymi użytkownikami języka. Zdolność do rozumienia komunikatów i tworzenia zrozumiałych wypowiedzi jest podstawowym miernikiem stopnia

${ }^{3}$ Por. W. Miodunka, Kompetencja socjokulturowa w nauczaniu języka polskiego jako obcego, w: Kultura w nauczaniu języka polskiego jako obcego: stan obecny-programy nauczania-pomoce dydaktyczne, red. W. Miodunka, Kraków 2004, s. 97-118. 
opanowania języka obcego. Odzwierciedla się to choćby w najbardziej powszechnym pytaniu o znajomość języka. Zapytamy przecież: „Czy mówisz po polsku?”, a nie: „Czy piszesz (czytasz) po polsku?”. Podobnie w innych językach: „Do you speak English?”, „Kannst du Deutsch sprechen?” czy wreszcie po koreańsku: „Hangukmaleul haseyo?”.

Najbardziej pierwotny i najpowszechniejszy sposób posługiwania się językiem to dialog (gr. diálogos = rozmowa), „tekst mówiony sam w sobie”. Jest czymś więcej niż następującymi po sobie monologowymi wypowiedziami dwóch (lub większej liczby) jego uczestników. Bardzo poetycko, chyba najtrafniej, ujął ten problem amerykański antropolog Lawrence Wylie: „Myślę o komunikacji jako o tańcu dwojga ludzi. Dźwięki są często tylko muzyka, która towarzyszy mającej miejsce komunikacji"s. Znajduje to pełne uzasadnienie w dwudziesto- i dwudziestopierwszowiecznych, licznych badaniach nad komunikacją niewerbalną, która coraz częściej bywa uwzględniana jako komplementarna wobec porozumiewania się wyłącznie za pomoca języka pojmowanego tradycyjnie, wyłącznie jako system gramatyczno-leksykalny ${ }^{6}$. Dale G. Leathers, autor prac dotyczących komunikacji niewerbalnej, wymienia cztery systemy, które składają się na metasystem komunikacji ludzkiej: werbalny, a poza nim słuchowy, wizualny ${ }^{7}$ i pozawzrokowy ${ }^{8}$.

Badania kognitywne udowodniły, że na poziomie ludzkiego umysłu niemożliwe jest rozdzielanie czysto językowych umiejętności od takich zdolności, jak postrzeganie wzrokowe czy motoryka ${ }^{9}$, co więcej: językowe ujmowanie świata jest wtórne wobec niejęzykowego. Właśnie dlatego tak wielkie znaczenie $\mathrm{w}$ badaniach nad językiem w procesie komunikacji ma uwzględnianie zarówno jej werbalnego, jak i niewerbalnego aspektu. Pełne uczestnictwo

${ }^{4}$ A. Załazińska, Niewerbalna struktura dialogu. W poszukiwaniu polskich wzorców narracyjnych i interakcyjnych zachowań komunikacyjnych, Kraków 2006, s. 30.

5 L. Wylie, Beaux Gestem: A Guide to French Body Talk, New York 1977, s. VII, cyt. za: B. Morcinek, Gesty po polsku i po japońsku - komunikacja niewerbalna w procesie nauczania języka polskiego jako obcego, w: Studia Polonistyczne w Azji. 2007 International Conference, red. B. Kwon Cheong, Seoul 2007, s. 139.

${ }^{6}$ Największy wpływ na rozszerzenie tych badań miał rozwój językoznawstwa kognitywnego, postulującego odwołanie do struktur myśli, które realizują się na wielu płaszczyznach językowego wyrażania.

7 W systemie komunikacji wizualnej D.G. Leathers wyróżnia trzy podsystemy: kinezyjny, proksemiczny oraz komunikację przez przedmioty. Zob. D.G. Leathers, Komunikacja niewerbalna, Warszawa 2007, s. 25-29. Por. ryc. 1.1, s. 28.

8 System komunikacji pozawzrokowej zawiera w systematyce D.G. Leathersa podsystemy: dotykowy, węchowy i czasowy.

9 Zob. R. Kalisz, W. Kubiński, Dwadzieścia lat językoznawstwa kognitywnego w USA i w Polsce - próba bilansu, w: Językoznawstwo kognitywne - wybór tekstów, red. W. Kubiński, R. Kalisz, E. Modrzejewska, Gdańsk 1998, s. 9-27. 
w płynnym procesie komunikacyjnym jest możliwe dopiero po połączeniu tych dwóch kodów. Luki w opanowaniu kodu pozawerbalnego mogą prowadzić do dezorientacji, a nawet nieprzyjemnych konsekwencji. O ile bowiem zasadniczo łatwo jest zrozumieć niekompetencję językową w zakresie systemu gramatycznego lub leksykalnego, o tyle jesteśmy często tak bardzo przekonani o uniwersalności naszych gestów, że ich nieznajomość lub niewłaściwe zastosowanie mogą wręcz budzić zastrzeżenia do kultury osobistej osoby, z którą się komunikujemy ${ }^{10}$. Komunikacja niewerbalna w bezpośrednim kontakcie niezwykle zbliża ludzi i pozwala wiele komunikatów przekazać w sposób ekonomiczny i precyzyjny, dlatego warto zadbać o to, by również w tym aspekcie porozumiewanie się z Innym było źródłem satysfakcji z udanych kontaktów, a nie frustracji, zdziwienia i nieporozumień. Przed nauczycielem języka obcego stoi zatem zadanie takiego skorelowania nauczania języka na obu poziomach, by kompetencja komunikacyjna była pełna.

Lektor - jako ambasador swej kultury - jest zobowiązany do możliwie pełnej prezentacji systemu języka przez włączenie także zagadnień poświęconych komunikacji parajęzykowej od samego początku kształcenia. Gesty najbardziej powszechne w systemie niewerbalnym są związane z tymi sytuacjami życia codziennego, które pojawią się też na pierwszym etapie nauczania języka. Należą do nich chociażby: powitanie i pożegnanie oraz przedstawianie się, potwierdzanie i zaprzeczanie czy sytuacje towarzyskie związane z jedzeniem i piciem. Pewną uniwersalność można założyć w przypadku najprostszych komunikatów niewerbalnych - tzw. gestów ikonicznych ${ }^{11}$. Gesty metaforyczne, które ilustrują abstrakcyjne pojęcia - wywodzące się za każdym razem z kodu ograniczonego kulturowo i społecznie - należy potraktować jako specyficzne elementy języka, wymagające komentarza i praktycznego treningu.

Praca ze studentami pochodzącymi z Europy, Ameryki oraz z Azji pozwoliła mi zaobserwować znaczne różnice w sposobie i tempie nauki języka polskiego u osób pochodzących z zachodniego kręgu kulturowego i z krajów azjatyckich. Duże różnice są też dostrzegalne w naturalnych sposobach reagowania w interakcji z nauczycielem. W przypadku słabej znajomości lub wręcz nieznajomości języka polskiego gesty odgrywają ogromną rolę w usprawnia-

10 Przed rozpoczęciem studiów nad kodem niewerbalnym byłam tak właśnie naiwnie przekonana o względnej uniwersalności niektórych gestów. Nie zdawałam sobie również sprawy ze złożoności kodu parajęzykowego i z tego, że jego opanowanie może być równie trudne, jak nauka fonetyki, gramatyki czy leksyki.

11 Gesty ikoniczne reprezentują bezpośrednie podobieństwo między strukturą pojęciową i formą gestu. To gesty konkretne i obrazowe - znaki rzeczy i zdarzeń. Zob. A. Załazińska, Schematy myśli wyrażane w gestach. Gesty metaforyczne obrazujace abstrakcyjne relacje $i$ zasoby podmiotu mówiqcego, Kraków 2001, s. 23-24. 
niu komunikacji. Na problem wagi komunikacji niewerbalnej zwróciła uwagę również Barbara Morcinek, lektorka pracująca od kilku lat na Tokijskim Uniwersytecie Studiów Międzynarodowych, w artykule Gesty po polsku i po japońsku - komunikacja niewerbalna w procesie nauczania języka polskiego jako obcego ${ }^{12}$ :

W nauczaniu języka polskiego jako obcego ten aspekt [połączenie kodu werbalnego i pozawerbalnego - I.J.] wydaje się jednak wciąż niewystarczająco wyeksponowany. Uświadomiłam to sobie w pełni, kiedy - wyposażona w gesty znane mi z kultury polskiej - komunikowałam się z Japończykami ${ }^{13}$.

Dzięki kontaktowi z grupą Koreańczyków przebywających na stypendiach w Poznaniu zebrałam bezpośrednie obserwacje oraz relacje samych studentów, na czym polegają istotne różnice w systemie niewerbalnym Polaków i mieszkańców Kraju Łagodnego Poranka ${ }^{14}$. Zanim zajmę się ich prezentacją i zestawieniem najbardziej charakterystycznych koreańskich gestów, omówię krótko źródła tych odmienności.

\section{Społeczeństwo koreańskie. Wpływy filozofii konfucjańskiej}

Półwysep Koreański aż do czasów wojny domowej pozostawał stosunkowo jednolity pod względem kulturowym. Mimo wielkiego skoku cywilizacyjnego, jaki pod wpływem industrializacji dokonał się na Południu w ciagu ostatnich kilkunastu lat, w kulturze i życiu społecznym nadal daje się zaobserwować bardzo silny wpływ konfucjanizmu, filozofii, a zarazem doktryny społecznej, która w Korei została zaakceptowana jako obowiązujący model edukacyjny już w IV wieku n.e. ${ }^{15}$. Umocnienie i kontynuacja tradycji konfucjańskiej (obok równolegle żywego w kulturze koreańskiej buddyzmu) dokonywały się przez kolejne wieki, aż do usankcjonowania jej w XV wieku przez króla Sejonga jako oficjalnej doktryny etycznej państwa.

Mimo że współcześnie Korea Południowa jest demokratycznym krajem wielowyznaniowym, zaś Koreańska Republika Ludowo-Demokratyczna pozostaje oficjalnie państwem świeckim, tradycja konfucjańska w znacznym stopniu reguluje zasady społecznego współżycia oraz codzienne kontakty ro-

12 Studia Polonistyczne w Azji, s. 137-157.

13 Ibidem, s. 139-140.

14 Taką nazwę nadał swemu państwu założyciel dynastii I (1392-1910), król I Song Ge

(H. Ogarek-Czoj, Religie Korei. Rys historyczny, Warszawa 1994, s. 99).

15 J.T. Kim, Confucianism and Korean Thoughts, Seoul 2000, s. 36. 
dzinne i w sferze publicznej zarówno na Północy, jak i na Południu ${ }^{16}$. Sprawia, że kulturę koreańska, podobnie jak chińska, japońską czy wietnamska, charakteryzuje odmienność tak bardzo odczuwana przez ludzi pochodzących z cywilizacji Okcydentu, objawiająca się przede wszystkim w silnej hierarchizacji życia społecznego ${ }^{17}$. Związana jest z systemem etycznym, który spadkobiercy Konfucjusza stworzyli na podstawie jego nauki i pism. Pryncypiami były w nim (i pozostają do dziś): odpowiedniość zachowania, praktyczna mądrość i właściwe relacje między członkami wspólnoty ${ }^{18}$. We współczesnym społeczeństwie koreańskim szczególnie ważne pozostają odpowiednie relacje w związkach rodzinnych i społecznych. Co więcej, charakter więzi rodzinnych przekłada się na wszelkie inne relacje, co wykażę w dalszej części artykułu, prezentując sposób realizacji zasad konfucjańskich w życiu codziennym Koreańczyków, nawet (a może szczególnie) w komunikacji niewerbalnej. Swoista „prorodzinność” i żywa obecność ducha powinności, które Konfucjusz ustanowił w relacjach interpersonalnych, wyjaśniają też w znacznym stopniu kolektywny charakter życia społecznego mieszkańców Kraju Łagodnego Poranka.

Jakie zatem są owe praktyczne zasady etyczne, regulujące stosunki międzyludzkie? To powinności, które wyznacza pięć typów relacji: przełożonego i podwładnego, ojca i syna, starszego brata i młodszego brata, męża i żony oraz między przyjaciółmi. Współcześnie jedynie ostatnia realizuje się w płaszczyźnie jednopoziomowej, bez - istotnego dawniej - hierarchizowania wynikającego z różnicy wieku. Wszystkie te wytyczne znajdują odzwierciedlenie w strukturze języka koreańskiego, zwłaszcza w rozbudowanym systemie nazw stopni pokrewieństwa: w formach adresatywnych (gdy członkowie rodziny zwracają się do siebie bezpośrednio) oraz klasyfikujących (kiedy mówi się o członkach swojej rodziny jako o osobach trzecich) ${ }^{19}$. Grzeczność w relacjach między członkami rodziny podkreślana jest także za pomocą form honoryfikatywnych, wpisanych inherentnie w system gramatyczny języka koreańskiego ${ }^{20}$. Hono-

${ }^{16} \mathrm{~W}$ tym artykule przedstawiam jedynie społeczeństwo południowej części Półwyspu Koreańskiego ze względu na możliwość bezpośredniego kontaktu wyłącznie z jego przedstawicielami.

${ }^{17}$ Konfucjanizm początkowo rozpowszechnił się w Chinach i Korei (być może na początku I wieku n.e.), a także w Wietnamie i Japonii, stając się dominującą doktryną państwowo-religijną wielu krajów Dalekiego Wschodu, kształtującą ich politykę i obyczaje do czasów współczesnych.

18 Zob. R. Harris, Roadmap to Korean, New Jersey-Seoul 2003, s. 22-23.

19 Por. T. Lisowski, Determinizm kulturowy a leksyka. Pięć powinności konfucjańskich a koreańskie nazwy stopni pokrewieństwa, w: Z zagadnień leksykologii i leksykografii języków stowiańskich, red. J. Kemper-Warejko, E. Kaproń-Charzyńska, Torun 2007, s. 401-413.

${ }^{20}$ Zob. R. Huszcza, Honoryfikatywność. Gramatyka, pragmatyka, typologia, Warszawa 1996, s. 51-56. Według R. Huszczy honoryfikatywność to „pewien szczególny rodzaj znaczenia 
ryfikatywność potraktować należy jako kategorię pragmatyczną - zarówno leksykalną i gramatyczną, jak i kulturową - również w zakresie komunikacji niewerbalnej.

Jako że „myśl jest nierozerwalnie związana z ciałem”21, a gesty są „pierwotnym sposobem obrazowania myśli, jak najbardziej ikonicznym i motywacyjno-wyobrażeniowym, wywodzącym się bezpośrednio z fizykalnego ludzkiego doświadczenia i jego bytowania w ontologicznej przestrzeni i czasie"22, tak ważne w rozumieniu natury i specyfiki danego narodu jako wspólnoty etnicznej (i etnolingwistycznej) jest przyglądanie się komunikacji niewerbalnej. W moich analizach zakładam wspomnianą już komplementarność kodu werbalnego i niewerbalnego, a także ich reprezentatywność w prezentowaniu kluczowych cech narodów. Zebrane przeze mnie zachowania niewerbalne zaobserwowane w kontakcie z Koreańczykami z Południa mogą stanowić podstawę dyskusji nad różnicami kulturowymi i społecznymi między grzecznością polską (europejską) a koreańską (opartą na tradycji konfucjańskiej).

\section{Język niewerbalny Koreańczyków w komunikacji}

Nauczanie języka niewerbalnego w procesie glottodydaktycznym w przypadku tak odległej kultury wypada rozpocząc od rozpoznania semantyki gestów, którymi posługują się studenci. Dobrym punktem wyjścia jest zebranie tych gestów, które w procesie kategoryzacji świata (w tym wypadku niejęzykowej ${ }^{23}$ ) pojawić się muszą, a zatem dotyczących obligatoryjnych obszarów społecznego funkcjonowania, takich jak powitanie i pożegnanie czy zachowania towarzyszące spożywaniu posiłków lub piciu alkoholu. Przyjrzę się tym

\footnotetext{
zawartego w treści wypowiedzi, a mianowicie jako informację o towarzysko-społecznej relacji między jej nadawcą a odbiorcą, relacji między nadawcą a słuchaczem, nie będącym bezpośrednim odbiorcą (adresatem wypowiedzi), oraz relacji między nadawcą a bohaterem wypowiedzi" (s. 51). R. Huszcza dokonuje omówienia form honoryfikatywnych w wielu językach świata. Wśród nich kategoria gramatyczna honoryfikatywności najintensywniej występuje w językach azjatyckich o tradycjach konfucjańskich, polszczyzna natomiast jest językiem honoryfikatywnie umiarkowanym.

${ }^{21}$ To teza G. Lakoffa z Woman, Fire and Dangerous Things, 1987, cyt. za: A. Załazińska, Schematy myśli wyrażane w gestach..., s. 16.

${ }_{22}$ J. Antas, Gest, mowa a myśl, w: Językowa kategoryzacja świata, red. R. Grzegorczykowa, A. Pajdzińska, Lublin 1996, s. 81.

${ }^{23}$ Odwołuję się tu przez analogię do kognitywistycznej tezy o językowej kategoryzacji świata, przypominając tezę Piageta: „źródłem operacji intelektualnych człowieka jest stadium sensomotoryczne, przedwerbalne, kiedy tworzą się pierwsze schematy poznawcze i schematy działania", cyt. za: A. Załazińska, Niewerbalna struktura dialogu..., s. 45.
} 
gestom, które Polakom mogą przysporzyć największych trudności, a jednocześnie są cennym źródłem wiedzy o kulturze koreańskiej. O ile bowiem studenci z Korei przebywający w Polsce najczęściej poprawnie i adekwatnie do sytuacji stosują językowe formuły grzecznościowe, o tyle często nie potrafia skorelować kompetencji lingwistycznej z całościowym kontekstem komunikacyjnym, w którym umieścić też należy komunikację niewerbalną. Odzwierciedla to ich tożsamość i odrębność kulturową, jednak problem może pojawić się, gdy interferencja zachowań niewerbalnych koreańskich i polskich wynikająca z dużego rozdźwięku między naszymi kodami gestualnymi prowadzi do zakłóceń komunikacyjnych.

Zacznę od przywołania sytuacji, która doskonale ukazuje specyfikę koreańskiej komunikacji niewerbalnej. Podczas obserwowanych przeze mnie zajęć lektoratowych z Koreańczykami po kilku minutach od rozpoczęcia lekcji cicho otworzyły się drzwi. Spóźniony student lekko się skłonił i kilka sekund czekał w milczeniu na znak nauczycielki. Dopiero po uzyskaniu zaproszenia na zajęcia przez nieco zaskoczoną niepewnością studenta lektorkę szybko i dyskretnie wszedł do sali. Krok za nim podążyła jego koleżanka, również Koreanka ${ }^{24}$. Sytuacja ta ukazuje, jak interferencja kodów kulturowych prowadzi do zaburzeń komunikacyjnych. Autorytet nauczyciela w kulturze Dalekiego Wschodu wynika z co najmniej dwu powinności konfucjańskich: szacunku podwładnego wobec przełożonego oraz młodszego brata wobec starszego brata, gdzie pojęcie „brat” możemy interkulturowo przełożyć na język polski jako „bliźni”. Naturalne dla Koreańczyka, nienaturalne z kolei dla polskiego lektora, jest przekonanie, że nauczyciel jako przełożony i starszy, zatem stojący wysoko w hierarchii szkolnej, będzie odpowiedzialny za nienaganne kształtowanie relacji między sobą a uczniami. Dlatego to on decyduje, czy wejście „spóźnialskich” do sali nie zakłóci porządku, co mogłoby przeszkodzić w pracy innym studentom, którzy stawili się na czas, a zatem przestrzegają kodeksu wspólnoty. Już zadanie pytania o możliwość wejścia do sali byłoby naruszeniem zasad porządku, dlatego spóźnieni studenci w milczeniu i nie przekraczając proksemicznych granic sala - korytarz, oczekiwali na reakcję nauczyciela.

W filozofii konfucjańskiej stosunek do Innego przejawia się w szacunku i podporządkowaniu, to część wiedzy nadprzyrodzonej, przez którą człowiek w codziennym życiu uzyskuje kontakt z Niebem (Nieskończonościa, Ostatecznością) ${ }^{25}$. Podstawową postawą w relacjach międzyludzkich według

${ }^{24} \mathrm{Na}$ lektoratach języka polskiego w poznańskim Studium Języka Polskiego dla Cudzoziemców stypendyści z Korei odbywają zajęcia w grupach jednorodnych, wyłącznie koreańskich.

${ }^{25}$ Por. J.T. Kim, op.cit., s. 6. Podaję kilka możliwych wyjaśnień pojęcia Niebo ze względu na nieprzystawalność terminów konfucjańskich i chrześcijańskich. 
Księgi przemian ${ }^{26}$, pierwszej z klasycznego pięcioksięgu konfucjańskiego, jest ,jing” - respekt, szacunek. Przez szacunek - jak głosi Ksiega - serce staje się prawe. Bezkompromisowy, jakkolwiek kontrowersyjnie by to zabrzmiało, szacunek w stosunku do nauczyciela jest zatem zgodny z niebiańskim porządkiem. To na nauczycielu spoczywa odpowiedzialność podjęcia takich działań, by uczniowie uzyskali odpowiednią wiedzę i umiejętności. W Azji model nauczania opartego na autorytecie, ze względu na podstawy filozoficzne relacji społecznych, panuje niemal absolutnie. Właśnie dlatego nauczanie ,niezeuropeizowanych" Koreańczyków przez Polaków bywa tak trudne. W odpowiedzi na pytanie lektora: „rozumiecie?” oczy wszystkich uczniów wyrażą często zdumienie: ,jak to? oczywiście, naszym obowiązkiem jest rozumieć, bo obowiązkiem nauczyciela jest przygotowanie jasnego wykładu". W nauczaniu Koreańczyków polskich realiów kulturowych warto podkreślać naszą tendencję do budowania relacji bardziej zbliżonej do partnerskiej i zachęcać do większej otwartości w kontakcie z nauczycielem.

Bardzo ważnym elementem komunikacji niewerbalnej są również gesty, które stanowią doskonały materiał do analiz interkulturowych. Gestem niezwykle urokliwym, a zarazem mocno osadzonym w azjatyckim kontekście, jest wyrażanie obietnicy. Osoby, które uczestniczą w akcie przysięgi, wyciągają przed siebie prawe dłonie i zakładaja za siebie ugięte małe palce. To gest funkcjonujący również w kulturze japońskiej, od Koreańczyków wiem jednak, że jego lokalna koreańska odmiana może zawierać dodatkowy element, jakim jest „przypieczętowanie” go zetknięciem kciuków ${ }^{27}$. Wyciagnnięcie przed siebie prawych rąk rozpoczyna również polski gest przysięgi, jest on jednak mniej subtelny i wysublimowany, poza tym - na co należy zwrócić uwagę studentom - właściwie paralelny wobec mocno skonwencjonalizowanego gestu powitania dwóch mężczyzn ${ }^{28}$. Jedyną różnicą może być tzw. przecięcie. To gest pojawiający się także w kontekście biznesowym, zatem jego pole semantyczne jest znacznie szersze niż gestu koreańskiego. Antropologiczna analiza prowadzi do hipotezy, że w Korei obietnica osobista nie jest transakcją. W Polsce prawie zawsze pojawia się dodatkowo komunikat werbalny o charakterze performatywnym: ,zgoda”, „umowa stoi”, „przyrzekam”, „przysięgam”. Na tę różnicę należy zwrócić uwagę obcokrajowcom.

${ }^{26}$ Księga przemian powstała najprawdopodobniej już w XI wieku p.n.e., jest księgą kanoniczną taoizmu oraz konfucjanizmu i do dziś stanowi jedno z najważniejszych źródeł filozoficznych społeczeństw azjatyckich.

${ }^{27}$ Może to znaczyć, że w Korei dopuszczalny jest nieco większy niż w Japonii kontakt cielesny. Przełamanie interkulturowych lodów i nawiązanie bezpośredniej relacji towarzyskiej jest łatwiejsze z Koreańczykami niż z Japończykami.

${ }^{28}$ W Korei stosuje się ukłony: głębsze lub płytsze, wykonywane z większą lub mniejszą pieczołowitością. 
W kontekście hierarchicznego układu społecznego panującego w Korei trzeba też pamiętać o tym, że po opisywany gest sięgnąć mogą jedynie osoby, które pozostają w relacji przyjacielskiej, zatem jednopoziomowej. Dotyk jest przekroczeniem granic intymności i dokonać się może jedynie za obopólnym przyzwoleniem członków aktu komunikacyjnego, ma też bardzo doniosłe znaczenie, jeśli występuje po raz pierwszy. W Polsce możliwy jest kontakt cielesny z przełożonym, na przykład uścisk dłoni przypieczętowujący uzgodnienie stanowiska dotyczącego wspólnych działań. Jego semantykę można określić jako obietnicę dobrej wzajemnej współpracy. Stanowi dopełnienie komunikatu: ze względu na relacje zachodzące między kanałem werbalnym i niewerbalnym gest ten należy uznać za powtórzenie. W kulturze koreańskiej taka nadwyżka jest dopuszczalna jedynie w kontaktach nieformalnych, bardzo ważne są bowiem oszczędność i precyzja. Gest przyrzeczenia ma również szczególne znaczenie ze względu na bardzo ograniczony na Dalekim Wschodzie udział bezpośredniego kontaktu fizycznego w komunikacji niewerbalnej. Dla konserwatywnych osób początkowo trudna do przyjęcia może być duża ekspansywność Polaków należących jednocześnie do kręgu kultur słowiańskich i do kultury śródziemnomorskiej, w których dość ważne jest ciepło i bliskość w relacji z partnerem komunikacji ${ }^{29}$. Proksemikę na pewno należy uznać za trudny element polskiego kodu niewerbalnego w nauczaniu Azjatów.

W każdej kulturze ważnym elementem życia społecznego są tradycje związane ze wspólnym piciem alkoholu. W Korei bardzo rozbudowany katalog zasad dotyczących wspólnej zabawy zakrapianej piwem, makkeolli ${ }^{30}$ lub $s o j u^{31}$, etykiety picia i gestów towarzyszących spożywaniu alkoholu szczególnie wyraziście ukazuje panowanie zasad konfucjańskich w codziennym życiu. Należy przy tym odróżnić sytuację towarzyską rówieśniczą od formalnej sytuacji zhierarchizowanej. W tym drugim przypadku bowiem nalewanie i picie alkoholu to czynność obwarowana określonymi rytuałami. Pije się z inicjatywy osoby najstarszej lub na wyższym stanowisku, ta osoba też zawsze płaci za innych, ponieważ wedle zasad społecznych to ona jest odpowiedzialna za

${ }^{29} \mathrm{~W}$ odniesieniu do grzeczności językowej pisze o tym problemie Małgorzata Marcjanik. Por. m.in. M. Marcjanik, Polskie normy grzecznościowe na tle innych kultur, w: Grzeczność w komunikacji językowej, Warszawa 2007, s. 22-26.

${ }^{30}$ Makkeolli to tradycyjny koreański alkohol destylowany z ryżu. Był bardzo popularny wśród rolników, dlatego nadano mu nazwę ,alkohol rolników”. Ma mleczny kolor.

${ }^{31}$ Soju to najbardziej popularny koreański alkohol, wyrabiany z ryżu, pszenicy, jęczmienia, driakwi lub batatów, zawierający w zależności od odmiany od 20 do $30 \%$ alkoholu. Koreańczycy nazywają soju „przyjacielem życia” i „powszechnym napojem”, zbliżającym ludzi, a ponieważ jest to wartość ponad wszelkie inne - cena soju jest niższa niż jakiegokolwiek innego alkoholu. 
wszystkich, którzy są od niej nie tylko młodsi, ale i mniej doświadczeni. Starszemu przysługuje prawo decydowania o wspólnocie.

Alkohol nalewa się w kolejności zgodnej z układem hierarchicznym wyznaczonym przez powinności konfucjańskie. Nie przystoi nalewać sobie alkoholu samemu, zawsze to sąsiad powinien napełnić nasz kieliszek. Po napełnieniu kieliszka sąsiada czekamy, aż on odwdzięczy się tym samym, co wyraża symbolicznie wzajemną dbałość braci o siebie. Nalewać alkohol należy zawsze dwoma rękoma - prawą trzymając butelkę, a lewą podtrzymując prawy nadgarstek (ewentualnie wyżej) albo - trzymając butelkę oburącz, jedną ręką u podstawy szyjki, a druga przy dnie butelki. Osoba, której nalano alkohol, powinna oburącz unieść kieliszek i wykonać lekki pokłon. Bardzo ważne jest bowiem oddawanie czci bratu, zwłaszcza starszemu, uszanowanie godności innych i zachowanie twarzy. Operowanie jedną ręką należy do zachowań nieprzystojnych, nie wpisuje się w kanon koreańskiej grzeczności i zasad honoryfikacji, zatem podobnie jak nie wolno jedną ręką nalewać alkoholu, nie można $\mathrm{w}$ ten sposób podać żadnego przedmiotu ${ }^{32}$. I - co ważne w kontaktach towarzyskich - raczej nie można uchylać się od picia alkoholu. Osoby, które nie nadążają za tempem wspólnego (sic!) picia (często kobiety) pozbywają się alkoholu w ukryciu, ale oficjalnie piją razem ze wszystkimi. Picie alkoholu można również w kontekście koreańskim uznać za kulturowo „nieprzyzwoite”: W sytuacji formalnej osoba, której ranga pragmatyczna jest niższa (na pewno kobieta), gdy pije, powinna zasłonić twarz i odwrócić głowę.

Dla Koreańczyków bardzo atrakcyjny wydaje się polski egalitaryzm picia alkoholu i możliwość swobodnego decydowania o tym, kiedy i ile chce się wypić. Nadążanie za tempem życia towarzyskiego polskich pracowników firmy koreańskiej w Polsce wymagało od moich znajomych Koreańczyków dużo wytrwałości, którą mogli przypłacić nawet zdrowiem. Polacy tam zatrudnieni co wieczór po pracy wychodzili na wspólne biesiadowanie, a koreańscy studenci, pracujący razem z nimi, mimo opadania z sił, obawiali się odmówić, by nie narazić się na odizolowanie od grupy. Mogłoby się to wiązać z utratą twarzy, co byłoby dla mieszkańca Kraju Łagodnego Poranka ogromnym ciosem, zupełnie niezrozumiałym dla Polaków. Właśnie dlatego tak ważne jest uświadomienie studentom, że naturalna dla większości Polaków asertywność w decydowaniu o ilości spożywanego alkoholu przysługuje w Polsce także przybyszom z Dalekiego Wschodu. Wobec polskiej grzeczności i zaproszenia do wspólnego picia wolno im zachować się wedle konfucjańskich tradycji niegrzecznie i odmówić picia w sposób otwarty osobie starszej od siebie, nawet przełożonemu.

32 Interferencja ojczystego kodu niewerbalnego ujawnia się, gdy studenci podają nauczycielowi kartkę z zadaniem domowym oburącz, na stojąco, a nawet lekko się kłaniając. 
Analiza zachowań niewerbalnych i skryptów społeczno-towarzyskich uwarunkowanych kulturowo ukazuje, jak ważne jest uwzględnienie nauczania tych aspektów kultury przy nauce polszczyzny w celu uniknięcia nieporozumień komunikacyjnych. Naturalnie idealną sytuacją jest, gdy lektor języka polskiego zapozna się również z zasadami grzeczności panującymi w kraju studentów. Wówczas dialog interkulturowy może być naprawdę żywy i rodzić się w dyskusji, w której obie strony definiują swoją kulturę w opozycji, lecz nie opozycyjnie, a komplementarnie do kultury Innego.

\section{Podsumowanie}

Obywatele świata, nawet z odległej Korei, coraz liczniej zjawiają się w Polsce, na niwie uniwersyteckiej choćby za sprawą umowy między Uniwersytetem Jagiellońskim i Uniwersytetem im. Adama Mickiewicza a Hankuk University of Foreign Studies. W obliczu rozszerzania promocji polszczyzny na cały świat należy tak uaktualniać programy nauczania języka polskiego jako obcego, by problemy grzeczności werbalnej, niewerbalnej i realioznawstwo kulturowe znalazły w nich trwałe i ważne miejsce. Celem zajęć z języka polskiego jako obcego powinno być, zgodnie z założeniami Karty Narodów Zjednoczonych, ,przyczynianie się do pokojowego współistnienia ludzkości [...], próby likwidacji istniejących uprzedzeń i stereotypów” i „rozwijanie umiejętności budowania tzw. mostów porozumienia między kulturami”"33.

Zagadnienie dialogu międzykulturowego między innymi przez oswajanie z odmiennymi kodami niewerbalnymi, uwarunkowanymi kulturowo, zdaje się marginalizowane lub niedoceniane $\mathrm{w}$ procesie nauczania języka polskiego. Wskazane przeze mnie przykłady pochodzące z kręgu koreańskiego ukazują, jak sądzę, konieczność głębokiego wniknięcia w kontekst kulturowy w celu rozpoznania zagrożeń interferencyjnych. Widzę w nim szansę rozwoju badań dialogu interkulturowego nie tylko w zakresie językoznawstwa. Pośrednio nauczanie elementów kultury sprzyja kreowaniu porozumienia, które stworzy warunki do działań politycznojęzykowych zmierzających do zacieśnienia współpracy między Europą a Dalekim Wschodem. Różnojęzyczność i znajomość wielu kodów kulturowych reprezentuje bowiem jeden $\mathrm{z}$ wymiarów interkulturowości. Przygotowanie takich programów nauczania polszczyzny, które uwzględnią możliwie najwięcej jej aspektów, włączając weń również dyskusję nad komunikacją niewerbalną i - szerzej - elementami kultury, jest ważnym

${ }^{33}$ P.E. Gębal, Program nauczania cudzoziemców realiów polskich, w: Kultura w nauczaniu języka polskiego jako obcego..., s. 131. 
zadaniem stojącym zarówno przed instytucjami sprawującymi pieczę nad nauczaniem polszczyzny obcokrajowców, ośrodkami uniwersyteckimi, jak i autorami kolejnych podręczników.

\section{Izabela Janicka}

\section{Nonverbal Communication of Koreans at the Background of Cultural Tradition. From the Perspective of Foreign Language Teaching Methodology}

The article deals with the question of teaching a nonverbal code in the foreign language learning process of students coming from Korea. The social principles of Confucian philosophy, generally recognized in the Far East, provide an important context explaining the problems of interference in nonverbal communication and of achieving cultural competence. Several types of nonverbal messages have been presented, with focus on the gestures - inadequate for the Polish cultural code - used by Koreans in communicative situations. It has been stressed that such aspects of the language must be considered in teaching Polish in order for students to achieve sociocultural competence parallely to linguistic competence. In the face of worldwide promotion of the Polish language, the inclusion of nonverbal communication and cultural realities should play a bigger role in the teaching programs and be seen as important, although often omitted elements. 
